\begin{tabular}{|c|c|c|c|c|c|}
\hline JRL & Vol. 13 & No.2 & Hal. 85 - 95 & $\begin{array}{c}\text { Jakarta, } \\
\text { Desember 2020 }\end{array}$ & $\begin{array}{c}\text { p-ISSN : 2085.38616 } \\
\text { e-ISSN : 2580-0442 }\end{array}$ \\
\hline
\end{tabular}

\title{
PERENCANAAN PENGOLAHAN TANAH TERKONTAMINASI MINYAK BUMI DENGAN TEKNIK BIOPILE KAPASITAS 2,2 $\mathrm{M}^{3}$
}

\author{
Arifudin \\ Pusat Teknologi Lingkungan, Badan Pengkajian dan Penerapan Teknologi., \\ Gedung 820 Geostek, Kawasan PUSPIPTEK, Tangerang Selatan, Banten \\ 15314 \\ e-mail : arifudinbtl08@gmail.com
}

\begin{abstract}
ABSTRAK.
Upaya penanggulangan tumpahan minyak bumi telah banyak dilakukan, namun hasilnya masih kurang memuaskan. Pengolahan tanah terkontaminasi dengan teknik biopile dipandang sebagai salah satu alternatif yang memiliki biaya pengolahan relatif rendah dan ramah lingkungan serta tidak memerlukan lahan yang luas, selain kondisi kelembaban dan ketersediaan udara yang dapat dikendalikan sehingga pertumbuhan bakteri dapat terjaga. Untuk meningkatkan aktivitas bakteri maka perlu dilakukan penambahan nutrisi dan oksigen. Tanah terkontaminasi bertekstur klei pada kondisi kelembaban tinggi memiliki sifat mudah mengembang dan lengket. Pada kondisi kelembaban rendah tanah menjadi lebih keras dan mudah pecah, sehingga perlu dilakukan penambahan bahan pencampur yaitu kompos $10 \%$ dan pasir $30 \%$. Penambahan ini mampu meningkatkan porositas dan kegemburan tanah sehingga sebaran udara di dalam tanah lebih merata. Tujuan kegiatan ini adalah merencanakan pengolahan tanah terkontaminasi minyak bumi melalui aplikasi teknologi biopile sehingga tanah olahan biopile dapat memenuhi Permen LH nomor 128 Tahun 2003.

Kata Kunci: Tanah terkontamiasi minyak bumi, klei, bahan pencampur, biopile
\end{abstract}




\title{
Planning for Crude Oil Contaminated Soil Treatment with Biopile Techniques with the Capacity of $2.2 \mathrm{~m}^{3}$
}

\begin{abstract}
There have been many efforts to combat oil spills, but the results are still unsatisfactory. Cultivation of contaminated soil using biopile techniques is seen as an alternative that has relatively low processing costs and is environmentally friendly and does not require large areas of land, besides humidity conditions and air availability can be controlled so that bacterial growth can be maintained. To increase bacterial activity, it is necessary to add nutrients and oxygen. Klei-textured contaminated soil in high humidity conditions has the property of swelling and stickiness. In low humidity conditions the soil becomes harder and breaks easily, so it is necessary to add mixing materials, namely $10 \%$ compost and $30 \%$ sand. This addition is able to increase the porosity and loose soil so that the air distribution in the soil is more even. The objective of this activity is to plan the processing of petroleum-contaminated soil through the application of biopile technology so that the bio-pile processed soil can meet the Minister of Environment and Forestry Regulation Number 128 of 2003.
\end{abstract}

Keywords: Crude oil contaminated soil, klei, blending agents, biopile. 


\section{PENDAHULUAN}

Upaya penanggulangan tumpahan minyak bumi telah banyak dilakukan baik dengan cara fisika, maupun kimia. Namun hasilnya masih kurang memuaskan. Selain itu penanganan limbah minyak bumi secara kimia dan fisika membutuhkan biaya yang besar dan menimbulkan polutan sekunder dibandingkan pengolahan secara biologi (Crawford dan Crawford 1996).

Pengolahan tanah terkontaminasi minyak bumi dengan teknik biopile dipandang sebagai salah satu alternatif yang memiliki biaya pengolahan relatif rendah dan ramah lingkungan. Selain itu biopile juga memiliki kelebihan diantaranya adalah lahan yang digunakan untuk proses bioremediasi tidak memerlukan lahan yang luas, kondisi kelembaban dan ketersedian udara dapat dikendalikan sehingga pertumbuhan bakteri dapat terjaga (Battele dan NFESC 1996).

Teknik biopile merupakan pengolahan tanah terkontaminasi minyak bumi secara biologi, dimana tanah terkontaminasi minyak bumi diletakkan di atas permukaan yang kedap air dapat berupa beton atau tanah liat yang dipadatkan dengan ketinggian tumpukan bisa mencapai 1 - 2,5 meter dan untuk meningkatkan aktivitas bakteri dalam proses penguraian senyawa hidrokarbon ke dalam tumpukan tanah tersebut ditambahkan aerasi dan nutrisi.

Keberadaan oksigen di dalam tanah sangat membatu dalam proses biodegrasi senyawa hidrokarbon, dimana bakteri memanfaatkan oksigen untuk pertumbuhan dan memproduksi enzim oksigenase yang akhirnya menghasilkan gas $\mathrm{CO}_{2}$ (Abid et al. 2014). Menurut Hwang et al. (2006), untuk menjaga proses biodegradasi tetap berlangsung setidaknya diperlukan 2 sampai $5 \%$ kadar oksigen di dalam tanah.

Kandungan oksigen yang rendah dapat menyebabkan kinerja biopile menurun dan menyebabkan terjadinya kondisi anaerob di biopile. Menurut Jorgensen et al. (2000); Kuo (2014) menyebutkan bahwa kondisi anaerob akan terjadi bila konsentrasi oksigen sangat rendah atau kurang dari $1 \%$, kondisi anaerob tersebut akan berpengaruh terhadap aktivitas bakteri aerob dan akan terbentuk gas $\mathrm{NH}_{3}$ sebagai akibat dari meningkatnya bakteri anaerob.

Unsur-unsur karbon, nitrogen dan fosfor merupakan unsur penting dalam pertumbuhan bakteri. Unsur karbon digunakan oleh bakteri sebagai sumber energi untuk aktivitasnya. Unsur nitrogen berperan penting dalam perbanyakan sel, pembentukan dinding sel, pembentukan asam amino dan enzimenzim. Sedangkan unsur fosfor berperan dalam pembentukan asam nukleat dan fosfolipid. Menurut Gao et al. (2014) pemberian nutrisi pada proses bioremediasi mampu meningkatkan degradasi senyawa hidrokarbon secara signifikan

Menurut Battele dan NFESC (1996); US EPA (2004) keberhasilan proses biodegradasi senyawa hidrokarbon minyak bumi dipengaruhi oleh beberapa faktor diantaranya adalah: tekstur tanah, $\mathrm{pH}$, kelembaban, nutrisi, suhu tanah dan kerapatan populasi bakteri

Tujuan kegiatan ini adalah merencanakan pengolahan tanah terkontaminasi minyak bumi melalui aplikasi teknologi biopile sehingga dapat memenuhi baku mutu menurut Permen LH nomor 128 Tahun 2003. 


\section{METODE PENELITIAN}

\subsection{Pengumpulan Data}

Tahap ini dimulai dengan melakukan survei ke lokasi, adapun survei yang dilakukan meliputi:

1. Survei lokasi untuk mendapatkan data-data awal tentang :

a. Lay out lahan calon lokasi pengolahan

b. Denah lokasi penempatan unit pengolahan tanah terkontaminasi minyak bumi

c. Data jenis kontaminan minyak bumi, kualitas tanah dan kendala-kendala yang muncul.

d. Data karakteristik kontaminan minyak bumi

e. Data fisika dan kimia tanah.

2. Survei kondisi fisik, seperti kondisi lingkungan di calon lokasi pengolahan.

\subsection{Perencanaan Desain Biopile}

Desain pengolahan tanah terkontaminasi minyak dengan teknik biopile yang direncanakan adalah sebagai berikut :

1. Pondasi biopile menggunakan beton dan untuk menghindari erosi oleh air hujan dan angin, biopile diberi atap yang terbuat dari polycarbon dan tiang terbuat dari rangkaian besi hollow.

2. Pile tanah terkontaminasi minyak berbentuk trapesium dengan kemiringan 50 derajat dan kadar kontaminan yang digunakan sebesar $5 \%$.

3. Bahan pencampur untuk menambah kegemburan dan porositas tanah tercemar minyak menggunakan kompos $10 \%$ dan pasir $30 \%$

4. Rasio C:N:P yang digunakan untuk penambahan nutrisi bakteri pendegradasi minyak bumi menggunakan

C:N:P : 100:5:1.

\section{HASIL DAN PEMBAHASAN}

\subsection{Perencanaan Pondasi Biopile}

Biopile dibuat dengan meletakkan tanah terkontaminasi minyak bumi di atas permukaan tanah klei dengan ketebalan minimum $60 \mathrm{~cm}$ setelah dipadatkan dan memenuhi batas permeabilitas $(\mathrm{K})$ minimum adalah 10 ${ }^{5} \mathrm{~cm} /$ detik (KepMenLH No 128, 2003), atau dapat diletakkan di atas permukaan beton dan diberi atap sebagai pelindung angin dan hujan (Kratzke et al. 1998).

Kriteria perencanaan:

Pondasi biopile : beton

Kemiringan

permukaan beton $\quad: 0,5-1 \%$

Pelindung biopile : polycarbon

Tiang pelindung biopile : besi hollow

Pada bagian luar pile di buat saluran air menuju bak penampungan, saluran air ini berfungsi untuk mengalirkan air lidih pile (tumpukan) tanah tercemar minyak menuju bak penampung lindi. Untuk menghindari limpasan air hujan dari lingkungan sekitar dibuat tanggul yang mengelilingi biopile.

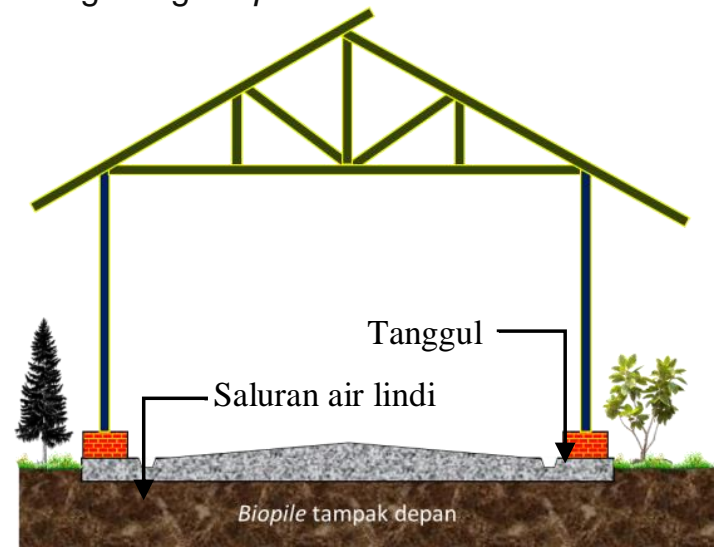

Gambar 1. Desain pondasi biopile tampak depan 


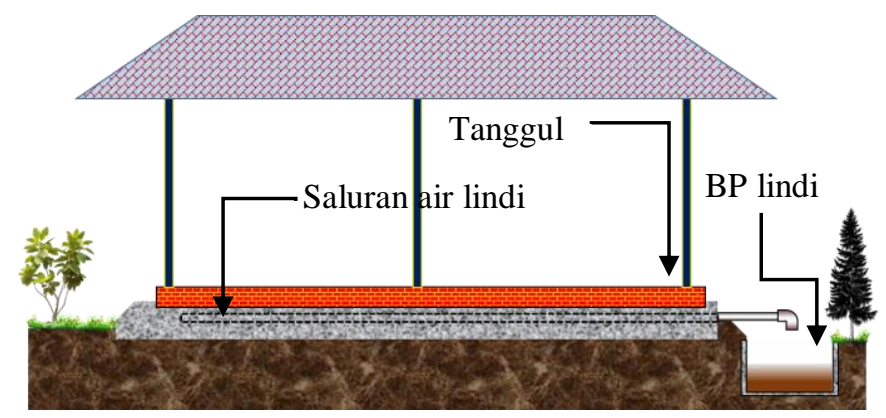

Gambar 2. Desain pondasi biopile tampak samping

\subsection{Tanah Terkontaminasi Minyak (Tanah mix).}

Keberadaan oksigen di dalam tanah terkontaminasi minyak bumi sangat dibutuhkan dalam pertumbuhan bakteri. Tanah bertekstur klei pada kelembaban tinggi sulit untuk mengalirkan udara dan distribusi nutrisi di dalam tanah tidak merata sehingga berdampak pada pertumbuhan bakteri (Vidali, 2001). Penambahan pasir dan kompos mampu meningkatkan porositas pada tanah sehingga udara lebih mudah tersebar ke seluruh tanah. Manurut Arifudin et al. (2016) penambahan kompos $10 \%$ dan pasir $30 \%$ pada tanah bertekstur klei dapat menggemburkan tanah dan menurunkan bobot isi tanah menjadi $0,84 \mathrm{gr} / \mathrm{cc}$. Rendahnya bobot isi mengindikasikan bahwa tanah tidak padat sehingga mudah mengalirkan udara dan meneruskan air. Menurut Nugroho (2009) tanah dengan bobot isi yang rendah akan lebih mudah ditembus oleh akar tanaman dan memiliki ketersedian oksigen lebih banyak dibandingkan dengan tanah dengan bobot isi yang tinggi

Kriteria Perencanaan Campuran Tanah Tercemar Minyak

Tekstur tanah : lom berklei

$\begin{array}{ll}\text { Porositas tanah } & : 54,5 \% \\ \text { Bobot isi } & : 0,84-0,9 \mathrm{gr} / \mathrm{cc} \\ \text { Kapasitas lapang } & : 34,2 \% \\ \text { Air tersedia } & : 12,5 \%\end{array}$

\subsection{Perencanaan Pile Tanah Terkontaminasi Minyak}

Biopile dibuat dalam bentuk trapesium dengan bagian bawah lebih luas dari pada bagian atas. Dengan kriteria perencanaan sebagai berikut:

$$
\begin{array}{ll}
\text { Kapasitas biopile } & : 2,2 \mathrm{~m}^{3} \\
\text { Tinggi pile } & : 0,8 \mathrm{~m} \\
\text { Panjang pile } & : 2,65 \mathrm{~m} \\
\text { Kemiringan pile } & : 50 \\
& \multicolumn{2}{l}{\begin{array}{l}
\mathrm{a} \\
=\mathrm{h} / \text { tangen } \alpha \\
\quad=0,8 / 1,19=0,67 \mathrm{~m}
\end{array}}
\end{array}
$$

$$
\begin{aligned}
\text { I } & =\mathrm{L}-2 \mathrm{a} \\
& =2,65-(2 \times 0,67) \\
& =1,305 \mathrm{~m}
\end{aligned}
$$

$$
V=h\left(I w+a w+a I+1,33 a^{2}\right)
$$$$
w=\frac{(V / h)-\left(a I+1,33 a^{2}\right)}{(I+a)}
$$$$
=(2,2 / 0,8)-[(0,67 \times 1,305)+
$$

$\left.\left(1,33 \times 0,67^{2}\right)\right]$

$$
=0,65 \mathrm{~m} \quad 1,305+0,67
$$

$\mathrm{W}$ total $\quad=\mathrm{w}+2 \mathrm{a}$

$$
=0,65+(2 \times 0,67)
$$




$$
=2 \mathrm{~m}
$$

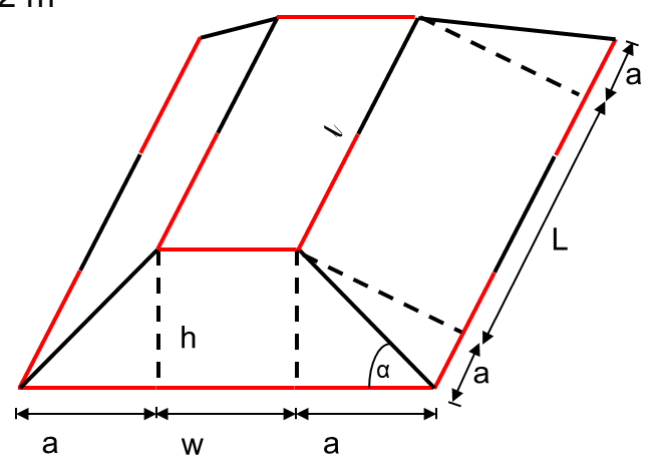

Jumlah minyak bumi di dalam tanah

Ditetapkan dimensi pile adalah sebagai berikut:

$\begin{array}{ll}\text { Panjang } & =2,65 \mathrm{~m} \\ \text { Lebar } & =2 \mathrm{~m} \\ \text { Tinggi } & =0,8 \mathrm{~m} \\ \text { Kemringan } & =50\end{array}$

\subsection{Kebutuhan Oksigen}

Oksigen merupakan factor penting dalam proses bioremediasi. Pada sistem biopile oksigen diberikan melalui sistem pemipaan aerasi dari blower.

Kriteri perencanaan:

Kapasitas biopile $\quad: 2,2 \mathrm{~m}^{3}$

$\begin{array}{ll} & : 1,9 \text { ton } \\ \text { Bobot isi tanah } & : 0,9 \mathrm{~g} / \mathrm{cc} \\ \text { Kadar minyak bumi } & : 5 \%\end{array}$

Lama proses bioremediasi: 60 hari

Diasumsikan rumus kimia dari senyawa hidrokarbon yang akan di degradasi adalah $\mathrm{C}_{7} \mathrm{H}_{16}$, dengan demikian maka persamaan reaksinya adalah sebagai berikut:

$\mathrm{C}_{7} \mathrm{H}_{16}+11 \mathrm{O}_{2}$<smiles>C=[Te]O[B]O</smiles>

$1 \mathrm{~mol}(100 \mathrm{~g}) \mathrm{C}_{7} \mathrm{H}_{16}$ membutuhkan 11 mol (352 g) oksigen, kandungan oksigen diudara $20 \%$. tercemar minyak adalah :

$$
\begin{array}{ll}
\text { Berat } \mathrm{C}_{7} \mathrm{H}_{16} & =5 \% \times 1900 \mathrm{~kg} \\
& =99,96 \mathrm{~kg}
\end{array}
$$

Volume udara $=\frac{100 \times 270780,02}{20 \times 1000}$

$$
=6769,5 \mathrm{~m}^{3}
$$

Debit udara $=0,0784 \mathrm{~m}^{3} /$ menit

$$
=78,4 \text { liter } / \text { menit }
$$

\subsection{Sistem Aerasi}

Aerasi merupakan faktor penting dalam proses bioremediasi. Pemberian aerasi di dalam proses biopile dilakukan dengan mengalirkan udara dari blower ke dalam pile tanah tercemar minyak melalui pipa aerasi. Pipa aerasi dibuat dari bahan pipa pvc yang diberi lubang. Pemberian lubang pipa dilakukan pada bagian bawah. Hal ini dilakukan untuk menghindari masuknya partikel tanah maupun material lainnya masuk ke dalam pipa perforated, lalu pipa perforated dibalut dengan ijuk atau sabut kelapa (Gambar 3).

Kriteria Perencanaan 


$$
\begin{array}{ll}
\text { Debit udara } & : \text { 78,4 liter/menit } \\
& : \text { (dibulatkan) liter/menit } \\
\text { Velocity } & : 3,15 \mathrm{~m} / \text { menit } \\
\text { Diameter pipa } & =\left(\frac{4 \times \text { debit udara }}{\Pi \times \text { Velocity }}\right)^{1 / 2} \\
& =0,18 \mathrm{~m} \\
& =7 \text { inci }
\end{array}
$$

Diameter pipa perforated

$$
\begin{aligned}
& =7 \text { inci } / 5 \\
& =1,4 \text { inci } \\
& =1,5 \text { inci } \\
& \text { (dibulatkan) }
\end{aligned}
$$

Panjang pipa perforated

$=$ panjang pile $-(2 \times$ tinggi pile $)$

$=2,65 \mathrm{~m}-(2 \times 0,8 \mathrm{~m})$

$=1,05 \mathrm{~m}$

Diameter lubang pipa perforated

$$
\begin{aligned}
& =\left(\frac{D^{2} \times S}{L \times 12}\right)^{1 / 2} \\
& =\left(\frac{2,25 \times 3}{41,3 \times 12}\right)^{1 / 2} \\
& =0,12 \mathrm{inci} \\
& =0,3 \mathrm{~cm}
\end{aligned}
$$

Lubang pipa

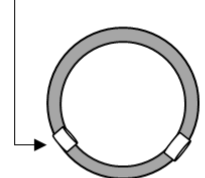

Tampak depan

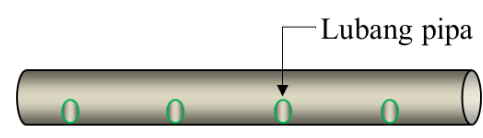

Tampak samping

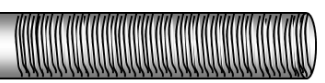

Pipa perforated yang telah dibalut

Gambar 3. Desain pipa perforated

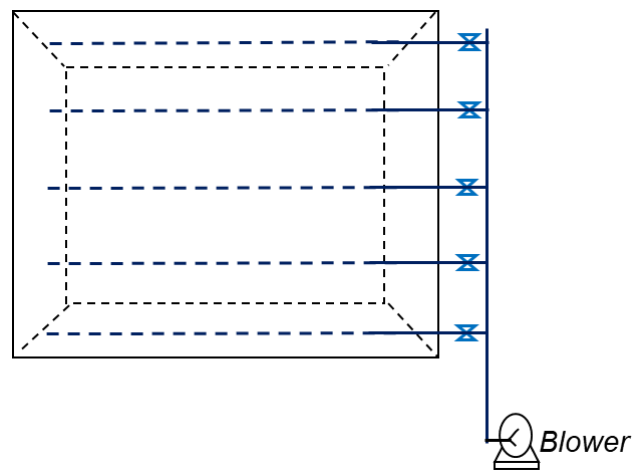

Gambar 4. Pemasangan pipa perforated di dalam biopile tampak atas

Penempatan pipa perforated di dalam pile tanah terkontaminasi minyak diletakkan pada bagian dasar pile dan bagian tengah. Hal ini dilakukan agar distribusi udara

menjadi lebih merata (Gambar 5 dan Gambar 6). 


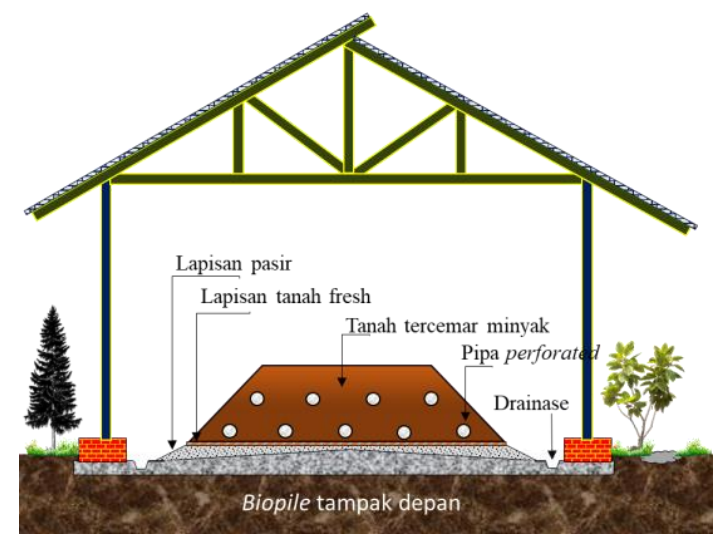

Gambar 5. Pemasangan pipa perfoted di dalam biopile tampak depan

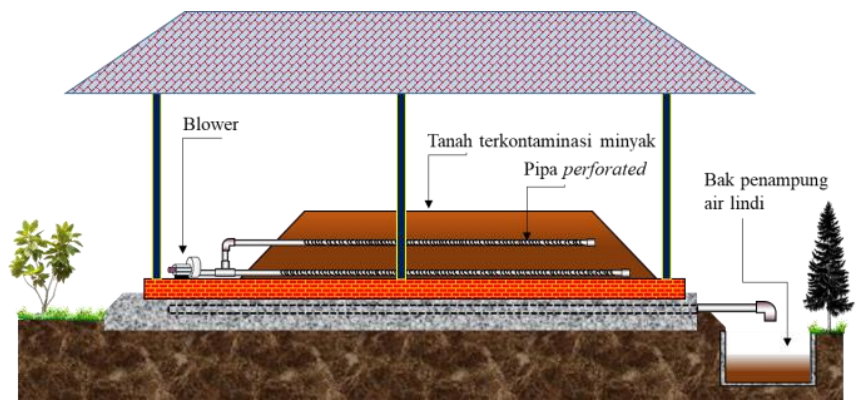

Gambar 6. Pemasangan pipa perforated di dalam biopile tampak samping

\subsection{Kebutuhan Nutrisi}

Unsur C (karbon), N (nitrogen) dan $P$ (posfor) merupakan unsur penting yang sangat diperlukan dalam pertumbuhan bakteri. Unsur unsur tersebut telah terdapat di alam, namun jumlahnya sedikit sehingga untuk meningkatkan pertumbuhan bakteri maka perlu ditambahkan tambahan nutrisi dari luar.

Kriteria Perencanaan :

$\begin{array}{ll}\text { Kapasitas biopile } & : 2,2 \mathrm{~m}^{3} \\ & : 1,9 \text { ton } \\ \text { Bobot isi tanah } & : 0,9 \mathrm{~g} / \mathrm{cc} \\ \text { Kadar minyak bumi } & : 5 \% \\ \text { Rasio C:N:P } & : 100: 5: 1 \\ \text { (Zam, 2010) } & \\ \text { Kadar kontaminan } & : 5 \%\end{array}$

Nutrisi yang digunakan: Urea $46 \%$ dan NPK $16 \%$.

Diasumsikan rumus kimia dari senyawa hidrokarbon yang akan di degradasi adalah $\mathrm{C}_{7} \mathrm{H}_{16}$

Kandungan minyak bumi di dalam tanah :

Berat minyak $=5 \% \times 1,9 \times 1000$

$$
=99,96 \mathrm{~kg}
$$

Perhitungan Nutrisi:

Berat $\mathrm{C}$ minyak

$=\underline{\text { atom relatif } \mathrm{C}_{7} \times \text { berat minyak }}$ molekul relatif $\mathrm{C}_{7} \mathrm{H}_{16}$

$$
=\frac{84 \times 99,96}{100}
$$

$=83,96 \mathrm{~kg}$ 
Rasio C: N: P ; $100: 5: 1$

Jumlah $\mathrm{N}$ yang dibutuhkan

$$
\begin{aligned}
& =\frac{83,96 \times 5}{100} \\
& =4,2 \mathrm{~kg}
\end{aligned}
$$

Jumlah $P$ yang dibutuhkan

$$
\begin{aligned}
& =\frac{83,96 \times 1}{100} \\
& =0,84 \mathrm{~kg}
\end{aligned}
$$

Bahan pembuatan nutrisi, menggunakan pupuk komersil, yaitu pupuk Urea $46 \%$ dan NPK 16\%,

\subsection{Kebutuhan Kelembaban}

Kelembaban sangat penting dalam pertumbuhan bakteri dan transportasi nutrisi. Namun demikian kelebihan kelembaban juga tidak bagus untuk pertumbuhan bakteri. Kelembahan yang tinggi pada tanah menyababkan sebagian besar pori tanah terisi oleh air dan hanya sebagian kecil yang dapat terisi oleh udara. Hal ini mengakibatkan ketersedian oksigen yang sangat dibutuhkan oleh bakteri untuk pertumbuhannya di dalam tanah menjadi berkurang. Menurut Chokshi dan Nelson (2003) melaporkan bahwa kadar air yang optimal untuk bioremediasi berkisar antara 15 sampai 20\%. Kadar air di atas $25 \%$ pada tanah klei mengakibatkan aktivitas bakteri menurun hal ini ditunjukan dengan menurunnya produksi gas $\mathrm{CO}_{2}$.

\footnotetext{
Kriteria perencanaan

Kapasitas Biopile $\quad: 2,2 \mathrm{~m}^{3}$

Kadar air tanah mix (campuran tanah tercemar minyak dengan kompos dan pasir : $15 \%$ Porositas tanah mix : 54,5\%
}

dengan demikian kebutuhan N NPK dan N Urea dapat di hitung.

$$
\begin{aligned}
& \begin{aligned}
\text { N NPK } & \frac{16 \% \times 0,84}{16 \%} \\
& =0,84 \mathrm{~kg}
\end{aligned} \\
& \begin{aligned}
\text { Kebutuhan NPK } & \frac{100 \times 0,84}{16} \\
& =5,247 \mathrm{~kg}
\end{aligned} \\
& \text { Kenutuhan N urea } \\
& =\frac{(4,2-0,84) \times 100}{46} \\
& =7,3 \mathrm{~kg}
\end{aligned}
$$

Ditetapkan kebutuhan pupuk untuk nutrisi bakteri adalah NPK 5,247 kg dan Urea 7,3 kg.

Kadar air yang diinginkan selama proses bioremediasi dengan teknik biopile

$24 \%$

Jumlah air yang dibutuhkan

$$
\begin{aligned}
& =2,2 \times 54,5 \% \times(24 \%-15 \%) \\
& =121,06 \text { Liter }
\end{aligned}
$$

\section{KESIMPULAN}

Berdasarkan hasil perencanaan pengolahan tanah terkontaminasi diperoleh beberapa kesimpulan sebagai berikut:

1. Pengolahan yang dipilih untuk mengolah tanah terkontaminasi minyak bumi adalah dengan teknik biopile.

2. Perencanaan biopile ini terdiri dari pondasi biopile, pelindung biopile, komposisi tanah tercemar minyak, sistem aerasi, nutrisi, dan kelembaban

3. Kebutuhan pupuk yang digunakan untuk meningkatkan pertumbuhan bakteri adalah NPK 5,247 kg dan Urea 7,3 kg

4. Kelembaban yang digunakan untuk proses bioremediasi adalah 24\%, Yaitu dengan 
menambahkan air sebanyak 121 liter ke dalam tanah mix

\section{v. DAFTAR PUSTAKA}

Abid A, Zaafouri K, Aydi A, Manai I, Aida, Messaoud C, Hamdi M. 2014. Feasibility of a Bioremediation Process Using Biostimulation with Inorganic Nutrient NPK for Hydrocarbon Contaminated Soil in Tunisia. $\mathrm{J}$ Bioremed Biodeg 5(4):1-6.

Arifudin, Yani M, Murtilaksono K, 2016. Bioremediasi tanah bertekstur klei terkontaminasi minyak bumi: aplikasi teknik biopile dengan penambahan pasir. JPSL. Vol. VI. Evaluasi Instalasi Pengolahan Air Limbah Industri Pengolahan Makanan. JAI, Vol. 11, No 1.

Battele, [NFESC] Naval Facilities Engineering Service Cente. 1996. Technical Memorandum TM2189-ENV: Biopile Design And Construction Manual. Port Hueneme (US): Battele Environmental Restoration Department.

Chokshi BG, Nelson YM. 2003. Optimization of High-Strength $\mathrm{Hy}$ drocarbon Biodegradation using Respirometry. Di dalam: Magar VS, Kelley ME, editor. In Situ and On-Site Bioremediation. Proceedings of the Seventh International In Situ and On-Site Bioremediation Symposium; 2003 June; Orlando (US): Battle Pr. hlm 0-10.

Crawford LD, Crawford LR. 1996. Bioremediation: Principles and Application. New York (US): Cambridge Univ Pr.

Gao YC, Guo SH, Wang JN, Li D, Wang H, Zeng DH. 2014. Effects of Different Remediation Treatments on Crude Oil Contaminated saline Soil. Chemosphere. 117 (2014): 486-497.
Hwang EY, Park JS, Kim JD, Namkoong W. 2006. Effects of Aeration Mode on the Composting of Diesel Contaminated Soil. J Ind Eng Chem. 12(5): 694-701.

Jorgensen KS, Puustinen J, Sourtti AM. 2000. Bioremediation of Petroleum HydrocarbonContaminated Soil by Composting in Biopiles. Env Poll. 107: 245-254

Kuo J. 2014. Practical Design Calculations for Groundwater and Soil Remediation. Second Edition. New York (US): CRC Pr.

[Kemen LH] Kementerian Negara Lingkungan Hidup . 2003. Keputuhan Menteri Lingkungan Hidup No 128 tahun 2003 Tentang Tatacara dan Persyaratan Teknis Pengolahan Limbah Minyak Bumi dan Tanah Terkontaminasi Limbah Minyak Bumi Secara Biologis. Jakarta(ID): Kementrian Negara Lingkungan Hidup.

Kratzke R, Major W, Fahnestock FV, Wickramanayake G. 1998. Biopile Design, Operation and Maintenance Handbook for Treating Hydrocarbon Contaminated Soils. Ohio (US): Battelle Pr.

Nugroho Y. 2009. Analisis Sifat Fisik-Kimia dan Kesuburan Tanah pada Lokasi Rencana Hutan Tanaman Industri PT Prima Multibuana. Hutan Tropis Borneo. 10(27): 222 -229.

[US EPA] United States Environmental Protection Agency. 2004 Chapter IV (Biopile) of OUST's publication: How to Evaluate Alternative Cleanup Technologies for Underground Storage Tank Sites: A Guide for Corrective Action Plan Reviewers. (EPA 510R-04-002). Washington DC (US): US EPA. 
Vidali M. 2001. Bioremediation. An Overview. Pure Applied Chem. 73(7):163-172.

Zam SI. 2010. Optimasi Konsentrasi Inokulum, Rasio C:N:P dan $\mathrm{pH}$ pada Proses Bioremediasi Limbah Pengilangan Minyak Bumi Menggunakan Kultur Campuran. El-Hayah. 1(2):23-34. 